\title{
Tyrosine Hydroxylase Neurons in the Male Hamster Chemosensory Pathway Contain Androgen Receptors and Are Influenced by Gonadal Hormones
}

\author{
STEPHEN E. ASMUS AND SARAH WINANS NEWMAN \\ Department of Anatomy and Cell Biology, Medical Science Building II, \\ University of Michigan, Ann Arbor, MI 48109-0616
}

\begin{abstract}
Chemosensory and hormonal signals, both of which are essential for mating in the male Syrian hamster, are relayed through a distinct forebrain circuit. Immunocytochemistry for tyrosine hydroxylase, a catecholamine biosynthetic enzyme, previously revealed immunoreactive neurons in the anterior and posterior medial amygdaloid nucleus, one of the nuclei within this pathway. In addition, dopamine-immunoreactive neurons were located in the posterior, but not the anterior, medial amygdala. In the present study, tyrosine hydroxylase-immunostained neurons were also observed in other areas of the chemosensory pathway, including the posteromedial bed nucleus of the stria terminalis and the posterior, lateral part of the medial preoptic area, while dopamine immunostaining was only seen in the posteromedial bed nucleus of the stria terminalis. The colocalization of tyrosine hydroxylase and androgen receptors was examined in these four tyrosine hydroxylase cell groups by a double immunoperoxidase technique. The percentage of tyrosine hydroxylase-immunolabeled neurons that were also androgen receptor-immunoreactive was highest in the posterior medial amygdaloid nucleus $(74 \%)$ and the bed nucleus of the stria terminalis $(79 \%)$. Fewer tyrosine hydroxylaseimmunostained neurons in the anterior medial amygdala (33\%) and the medial preoptic area (4\%) contained androgen receptors. Surprisingly, castration resulted in a significant decrease in the number of tyrosine hydroxylase-immunoreactive neurons only in the anterior medial amygdaloid nucleus, and this effect was transient. Six weeks after castration, the anterior medial amygdala contained 61\% fewer tyrosine hydroxylase-immunolabeled neurons, but 12 weeks after gonadectomy, immunostaining returned to intact values. The number of immunostained neurons in testosterone-replaced, castrated hamsters was not significantly different from that of intact or castrated animals at any time. The results of this study indicate that a substantial number of tyrosine hydroxylase-immunostained neurons in the chemosensory pathway are influenced by androgens; the majority of these neurons in the posterior medial amygdala and the posteromedial bed nucleus of the stria terminalis produce androgen receptors, and tyrosine hydroxylase immunoreactivity is altered by castration in the anterior medial amygdala. 1993 Wiley-Liss, Inc.
\end{abstract}

Key words: steroid, Syrian hamster, amygdala, bed nucleus of the stria terminalis, medial preoptic area

The medial nucleus of the amygdala (Me), bed nucleus of the stria terminalis (BNST), and medial preoptic area (MPOA) are central structures in the chemosensory pathway that control male reproductive behavior (Sachs and Meisel, '88). In the male Syrian hamster (Mesocricetus auratus), bilateral electrolytic lesions of any of these brain nuclei (Lehman et al., '80; Lehman and Winans, '82; Powers et al., '87) or transection of the fiber bundles connecting them (Lehman et al., '83) alters mating behavior, and Fos immunocytochemistry reveals a selective pat- tern of neuronal activation in these same regions following mating (Kollack and Newman, '92). In addition to relaying chemosensory information, neurons in the hamster $\mathrm{Me}$, BNST, and MPOA concentrate gonadal steroids (Krieger et al., '76; Doherty and Sheridan, ' 81 ; Wood et al., '92). These

Accepted January 25, 1993.

Send reprint requests to Dr. Sarah Winans Newman, Department of Anatomy and Cell Biology, Medical Science Building II, University of Michigan, Ann Arbor, MI 48109-0616. 
brain regions, therefore, are thought to represent sites of integration of chemosensory and hormonal signals, both of which are essential for reproduction in this species (Beach and Pauker, '49; Murphy and Schneider, '70; Devor, '73; Whalen and DeBold, '74; Powers and Winans, '75; Morin and Zucker, '78; Lisk and Bezier, '80; Powers et al., '85). Although the mechanisms of this integration are not fully understood, previous studies in the hamster and rat have shown that gonadal steroids alter the neuronal morphology (Gomez and Newman, '91), electrophysiology (Pfaff and Pfaffman, '69; Kendrick and Drewett, '79; Nabekura et al., '86; Wong and Moss, '92), and neurotransmitter production (Simerly and Swanson, '87; Simerly, '90; Swann and Newman, '92) in neurons of this circuit. In the hamster, these effects of gonadal steroids presumably influence the transmission of behaviorally essential chemosensory signals.

Little is known about the neurotransmitters in the anterior region of $\mathrm{Me}(\mathrm{MeA})$ or about the influence of gonadal hormones on their production. In the hamster, changes in dendritic morphology (Gomez and Newman, '91) and neurotransmitter production (Swann and Newman, '92) after castration have only been observed in the posterior region of $\mathrm{Me}(\mathrm{MeP})$. However, lesions of $\mathrm{MeA}$ eliminate male hamster mating behavior (Lehman et al., '80; Lehman and Winans, '82), while lesions of MeP only alter the temporal sequence of this behavior (Lehman et al., '83). In addition, the connections of anterior and posterior $\mathrm{Me}$ are distinctly different (Gomez and Newman, '92).

Recently, a species-specific population of tyrosine hydroxylase-immunoreactive (TH-IR) neurons was reported in the hamster Me (Asmus et al., '92). Two distinct groups of cells that contain $\mathrm{TH}$, the first and rate-limiting enzyme in the catecholamine biosynthetic pathway, are located in the anterior and posterior regions of this nucleus. These cells are not immunoreactive for dopamine- $\beta$-hydroxylase (DBH) or phenylethanolamine- $N$-methyltransferase (PNMT), enzymes that synthesize norepinephrine and epinephrine, respectively. Further, MeP contains dopamine-IR neurons. Taken together, these data suggest that the TH-IR cells in $\mathrm{MeP}$ produce dopamine, while those in MeA may produce immunocytochemically undetectable quantities of dopamine, or they may only produce its precursor, L-3,4dihydroxyphenylalanine (L-DOPA), which itself is a neurotransmitter candidate (Goshima et al., '88; Kubo et al., '92; Nakamura et al., '92). Whether these neurons synthesize dopamine or L-DOPA as an endproduct, they provide an interesting model in which to study the hormonal and chemosensory regulation of a specific subset of neurochemically identifiable cells in the chemosensory pathway.

The first objective of this study was to determine whether TH-IR neurons are located in areas of the chemosensory pathway other than $\mathrm{Me}$ and whether any of these areas also contain dopamine immunoreactivity. Second, immunocytochemical techniques were used to determine whether any of the TH-IR neurons in this pathway produce androgen receptors (AR). Finally, to test the hypothesis that gonadal steroids influence TH production in neurons of the chemosensory pathway, the numbers of TH-IR neurons in distinct subdivisions of this pathway were compared in intact, castrated and testosterone-replaced, castrated animals. Several postcastration intervals were studied because specific components of male hamster copulatory behavior are lost at different time points during the 12 week period following castration, after which mating is essentially eliminated, apart from sporadic mounts (Morin and Zucker, '78).

\section{MATERIALS AND METHODS Animals and experimental design}

Adult male Syrian hamsters (90-110 g; Charles River, Wilmington, MA) were group housed in a 14 hour light: 10 hour dark illumination cycle and given food and water $a d$ libitum. In Experiment I, the distribution of TH-IR neurons in the chemosensory pathway was examined in 20 animals pretreated with colchicine, an axoplasmic transport inhibitor (Dahlstrom, '68) that enhances TH and dopamine immunostaining (Simerly et al., ' 85 ; Kitahama et al., '89; Kitahama et al., '90; Asmus et al., '92). To examine the distribution of dopamine immunostaining in these areas, four colchicine-treated and two untreated animals were used for dopamine immunocytochemistry. In Experiment II, TH and AR colocalization was studied in three colchicine-treated and three untreated animals. In Experiment III, the effects of castration on $\mathrm{TH}$ immunostaining were examined by dividing 60 animals into the following three treatment groups: 1$)$ intact $(n=20), 2)$ castrated $(n=20)$, and 3 ) castrated plus testosterone $(n=20)$. At 2 , 4,6 , and 12 weeks after castration, five animals from each of these three groups were pretreated with colchicine and processed for $\mathrm{TH}$ immunocytochemistry. In two of the experimental groups, one animal died during the experiment before the data were obtained.

$\begin{array}{llll} & & & \\ & & \text { Abbreviations } & \\ \text { ACo } & \text { anterior cortical amygdaloid nucleus } & \text { MI } & \text { massa intercalata } \\ \text { AR } & \text { androgen receptors } & \text { MPN } & \text { medial preoptic nucleus } \\ \text { AR-IR } & \text { androgen receptor-immunoreactive } & \text { MPOA } & \text { medial preoptic area } \\ \text { BNST } & \text { bed nucleus of the stria terminalis } & \text { oc } & \text { optic chiasm } \\ \text { BNSTpi } & \text { bed nucleus of the stria terminalis, posterointermediate } & \text { ot } & \text { optic tract } \\ \text { BNSTpl } & \text { bed nucleus of the stria terminalis, posterolateral } & \text { PLCo } & \text { posterolateral cortical amygdaloid nucleus } \\ \text { BNSTpm } & \text { bed nucleus of the stria terminalis, posteromedial } & \text { PMCo } & \text { posteromedial cortical amygdaloid nucleus } \\ \text { DBH } & \text { dopamine- } \beta \text {-hydroxylase } & \text { PNMT } & \text { phenylethanolamine- } N \text {-methyltransferase } \\ \text { f } & \text { fornix } & \text { sm } & \text { stria medullaris } \\ \text { L-DOPA } & \text { L-3,4-dihydroxyphenylalanine } & \text { st } & \text { stria terminalis } \\ \text { Me } & \text { medial nucleus of the amygdala } & \text { T } & \text { testosterone } \\ \text { MeA } & \text { medial nucleus of the amygdala, anterior } & \text { TH } & \text { tyrosine hydroxylase } \\ \text { MeAD } & \text { medial nucleus of the amygdala, anterodorsal } & \text { TH-IR } & \text { tyrosine hydroxylase-immunoreactive } \\ \text { MeAV } & \text { medial mucleus of the amygdala, anteroventral } & \text { V } & \text { lateral ventricle } \\ \text { MeP } & \text { medial nucleus of the amygdala, posterior } & \text { III } & \text { third ventricle } \\ \text { MePD } & \text { medial nucleus of the amygdala, posterodorsal } & & \end{array}$




\section{Experiment I: TH and dopamine immunocytochemistry}

Hamsters were anesthetized with sodium $(\mathrm{Na})$ pentobarbital $(10 \mathrm{mg} / 100 \mathrm{~g}$ body weight, ip) and given $200 \mu \mathrm{g}$ of colchicine (Sigma, St. Louis, MO) in $2.5 \mu$ l of distilled $\mathrm{H}_{2} \mathrm{O}$ into the lateral ventricle (Neal and Newman, '89). After 48 hours, hamsters to be used for TH immunocytochemistry were deeply anesthetized and perfused through the ascending aorta with $150 \mathrm{ml}$ of $0.1 \mathrm{M} \mathrm{Na}$ phosphate-buffered saline containing $0.1 \% \mathrm{Na}$ nitrite for vasodilation, followed by $250 \mathrm{ml}$ of $4 \%$ paraformaldehyde in $0.1 \mathrm{M} \mathrm{Na}$ phosphate buffer (NaPB). The brains were removed and postfixed for 1 hour in the perfusion fixative and cryoprotected overnight in $20 \%$ sucrose in $\mathrm{NaPB}$ at $4^{\circ} \mathrm{C}$. Coronal brain sections (40 $\mu \mathrm{m}$ ) were cut on a freezing microtome, collected in $\mathrm{NaPB}$ containing $0.01 \% \mathrm{Na}$ azide, and stored at $4^{\circ} \mathrm{C}$.

Colchicine-treated and untreated hamster brains were prepared for dopamine immunocytochemistry according to a previously described protocol (Asmus et al., '92). Briefly, hamsters were perfused with distilled $\mathrm{H}_{2} \mathrm{O}$ containing $2 \%$ $\mathrm{Na}$ chloride and $1 \% \mathrm{Na}$ metabisulfite $(\mathrm{pH} 7.2)$ followed by $5 \%$ glutaraldehyde and $1 \% \mathrm{Na}$ metabisulfite in $50 \mathrm{mM} \mathrm{Na}$ cacodylate buffer ( $\mathrm{pH}$ 7.6). Brains were postfixed for 1 hour in the perfusion fixative and cryoprotected overnight in $20 \%$ sucrose and $1 \% \mathrm{Na}$ metabisulfite in $50 \mathrm{mM}$ Tris $(\mathrm{pH}$ 7.2). Brains were cut and stored as described above.

The monoclonal TH antibody (Incstar, Stillwater, MN) used in this study was raised in mouse against $\mathrm{TH}$ purified from PC-12 cells, and has been shown to be specific for TH according to Western blot analysis (Wolf et al., '89). Omission of the primary antibody or the secondary (goat antimouse) antiserum abolished all immunostaining. The dopamine antiserum (Eugene Tech Intl., Allendale, N.I) was raised in rat against dopamine coupled to Limulus hemocyanin by glutaraldehyde.

For TH immunostaining, free-floating brain sections at $120 \mu \mathrm{m}$ intervals were rinsed in $0.02 \mathrm{M}$ potassium phosphate-buffered saline (KPBS) and then incubated with the TH antibody (diluted to $1: 10,000$ with KPBS containing $0.3 \%$ Triton-X) for 48 hours at $4^{\circ} \mathrm{C}$. Sections were then incubated at room temperature for 1 hour each in goat anti-mouse antiserum (Jackson ImmunoResearch, West Grove, PA; 1:100 in KPBS with 0.3\% Triton), followed by mouse peroxidase anti-peroxidase (PAP) complex (Jackson ImmunoResearch; 1:200 in KPBS with $0.3 \%$ Triton and $4 \%$ normal goat serum). Each incubation was followed by three washes in KPBS ( 4 minutes each). To visualize the bound peroxidase, sections were incubated in a solution of $0.0125 \%$ diaminobenzidine tetrahydrochloride (DAB; Sigma), 0.015\% nickel chloride $\left(\mathrm{NiCl}_{2}\right)$, and $0.06 \%$ hydrogen peroxide $\left(\mathrm{H}_{2} \mathrm{O}_{2}\right)$ in KPBS for 6 minutes at room temperature. Sections were mounted onto gelatin-coated slides, dehydrated, cleared, and coverslipped with Permount. Adjacent sections were stained with cresyl violet for cytoarchitectural analysis.

For dopamine immunocytochemistry, brain sections were incubated with the dopamine antiserum diluted with $1 \% \mathrm{Na}$ metabisulfite, $0.5-1 \%$ Triton-X, $0.05 \%$ bovine serum albumin (BSA), and $0.05 \% \mathrm{Na}$ azide in $50 \mathrm{mM}$ Tris for 12 hours at room temperature. Sections were then incubated at room temperature for 1 hour each with biotinylated goat anti-rat antiserum (Sigma; 1:100 in 0.1 M NaPBS with $0.05 \%$ BSA, $0.5 \%$ Triton-X, and $2 \%$ normal rabbit serum) followed by the Elite Vectastain avidin-biotin complex solution (Vector Labs, Burlingame, CA) diluted with the same buffer. Each incubation was followed by washes in $0.1 \mathrm{M} \mathrm{NaPBS}$ containing $0.05 \%$ BSA. Bound peroxidase was visualized as described above.

Immunostained sections at $120 \mu \mathrm{m}$ intervals were examined by using brightfield illumination on a Leitz Dialux microscope. This sampling provided three to four sections per brain through each of the regions that contained TH-IR cell groups (MeA, MeP, BNST, and MPOA). Adjacent, cresyl violet-stained sections were examined to ensure that the same antero-posterior level through each of these areas was compared in different animals. The specific levels studied are as described in the Results section. A cell was considered labeled for TH or dopamine if its soma was filled with dark reaction product and at least one immunostained process could be seen emanating from the cell body. Every immunostained neuron in the nuclear area to be sampled was counted. Because the data are reported as the number of immunostained neurons per section rather than an approximation of the total number of neurons in any given region and because the sampling interval $(120 \mu \mathrm{m})$ was large compared with the average size of neurons in these areas $(15 \mu \mathrm{m})$, no correction factors were needed to compensate for double-counting errors. This sampling method was also used for quantification of TH-IR neurons in the colocalization and castration studies described below.

\section{Experiment II: AR/TH immunocytochemistry}

To determine whether TH-IR neurons in the chemosensory pathway contain AR, a double immunoperoxidase technique was used. The polyclonal AR antiserum, kindly provided by Dr. Gail S. Prins (University of Illinois College of Medicine), was raised in rabbit against a synthetic peptide corresponding to amino acids $1-21$ of the rat and human AR (Prins et al., '91). Specificity of this antiserum was confirmed by Western blot analysis (Prins et al., '91) and by blocking studies with the antigenic peptide (Prins et al., '91; Wood and Newman, '93a).

Colchicine- and noncolchicine-treated hamster brains were prepared for immunocytochemistry as described above under Experiment I. Brain sections at $120 \mu \mathrm{m}$ intervals were incubated with $4 \%$ normal goat serum and $0.3 \%$ Triton-X in KPBS for 1 hour at room temperature. Sections were then incubated with the AR antiserum $(1: 2,000)$ for 48 hours at $4^{\circ} \mathrm{C}$, followed by a biotinylated goat anti-rabbit antiserum (Vector Labs) for 1 hour, both diluted in the same buffer as above, and finally with the Elite Vectastain avidin-biotin complex solution (Vector Labs) diluted in KPBS plus $0.3 \%$ Triton-X for 1 hour. Each incubation was followed by KPBS rinses. Bound peroxidase was visualized as described above with $\mathrm{NiCl}_{2}$-intensified $\mathrm{DAB}$ as the chromagen. Following rinses in KPBS, these sections were processed for TH immunocytochemistry in the same manner detailed above except that $\mathrm{NiCl}_{2}$ was omitted from the $\mathrm{DAB} / \mathrm{H}_{2} \mathrm{O}_{2}$ solution.

Cells double-labeled for AR and TH contained black nuclei (AR/intensified DAB) surrounded by reddish-brown cytoplasm ( $\mathrm{TH} /$ unintensified $\mathrm{DAB}$ ) in the same focal plane. From the three colchicine-treated hamsters, the total number of TH-IR neurons and the number of double-labeled neurons were counted at $120 \mu \mathrm{m}$ intervals in sections through the appropriate antero-posterior levels of MeA, MeP, BNST, and MPOA as described above. From these data, the percentage of TH-IR neurons containing AR was determined for each region per brain. To determine whether the extent of colocalization varied between regions, the 
mean percentages of double-labeled cells were compared by a one-way analysis of variance (ANOVA) with post hoc pairwise comparisons (Scheffe F-test). A $P$ value of less than 0.05 was considered significant.

To ensure that colchicine treatment did not alter AR immunostaining, the number of AR-IR cells in a defined area of Me and BNST was compared in colchicine- and noncolchicine-treated hamsters. Finally, noncolchicinetreated brains were examined to look for double-labeling in the small number of TH-IR neurons that are immunostained in Me, BNST, and MPOA without colchicine.

\section{Experiment III: effects of castration on TH immunostaining}

Anesthetized hamsters were castrated via a midline scrotal incision at 10 weeks of age. Immediately thereafter, either a $20 \mathrm{~mm}$ Silastic capsule (1.98 $\mathrm{mm}$ inner diameter; $3.18 \mathrm{~mm}$ outer diameter; Dow Corning, Midland, MI) containing crystalline testosterone (T) (Sigma) or an empty capsule was implanted subcutaneously (Powers et al., '85). This capsule size maintains a constant, physiological level of serum $\mathrm{T}$ in the hamster (Campbell et al., '78).

After the predetermined postcastration interval, animals were treated with colchicine and perfused as described above under $\mathrm{TH}$ immunocytochemistry. To verify the efficacy of the hormone implants, two androgen-sensitive tissues were assessed at the time of perfusion. The average rostrocaudal length of the left and right sebaceous flank glands (Giegel et al., '71) was determined for each animal, and the gross size of the seminal vesicles was noted.

Immunocytochemistry for $\mathrm{TH}$ was carried out as described under Experiment I. To control for variation in immunocytochemistry, brain sections from each of the three treatment groups were processed simultaneously,

The mean number of TH-IR neurons per section was calculated from counts on three to four sections per brain at $120 \mu \mathrm{m}$ intervals, for each of the four areas studied (MeA, MeP, posteromedial BNST, and lateral MPOA) as described under Experiment I. Immunostained neurons were counted in brain regions ipsilateral to the colchicine injection by an observer blind to the animal's experimental group. These values were compared in intact, castrated, and T-replaced, castrated hamsters by a two-way ANOVA, with group and time after castration as factors. Post hoc pairwise comparisons were made with a Scheffe F-test with a $P$ value of less than 0.05 considered significant.

\section{RESULTS \\ Distribution of TH- and dopamine-IR neurons in Me, BNST, and MPOA}

The distribution of TH-IR neurons in Me of colchicinetreated hamsters was identical to that reported previously (Asmus et al., '92). Two well-defined populations of TH-IR neurons were located in $\mathrm{Me}$, one in MeA (Figs. 1A, 2A), and the other in MeP (Figs. 1B, 2B). The rostral boundary of the TH-containing cell group in MeA coincided with the rostral edge of the posterolateral cortical amygdaloid nucleus (PLCo). The caudal boundary of this cell group corresponded to the level at which the intercalated cell mass coalesces into a single cluster of cells, and the PLCo is the same cross-sectional area as the anterior cortical amygdaloid nucleus. The rostral border of the TH-IR cell group in $\mathrm{MeP}$ was dorsal to the rostral edge of the posteromedial cortical amygdaloid nucleus. This cell group in $\mathrm{MeP}$ extended to the caudal boundary of the nucleus.

Tyrosine hydroxylase-containing neurons were also observed in other areas of the chemosensory pathway. In the BNST, the largest number of TH-IR neurons was consistently found in the rostral part of the posteromedial subdivision (BNSTpm) (Figs. 1C, 2C), referred to as the "encapsulated" BNST in the rat (Simerly and Swanson, '86). Approximately 20 TH-IR neurons per section were observed in this region, which extends in the rostrocaudal direction from the caudal border of the body of the anterior commissure to the level at which the fornix and stria medullaris fiber bundles separate. A smaller number of cells were located at this level in the posterolateral BNST (BNSTpl) (Figs. 1C, 2C) and, at more caudal levels, in the preoptic BNSTpm (Figs. 1D, 2D). Very few TH-IR neurons were found in the posterointermediate BNST (BNSTpi) or any of the anterior subdivisions of the BNST.

Throughout the MPOA, the classically described periventricular dopaminergic neurons were immunoreactive for TH (Hökfelt et al., '84). In addition, a limited number of TH-IR neurons were visible in the lateral part of the MPOA at the level of the body of the anterior commissure. Caudally, a large number of TH-IR neurons were scattered throughout the lateral part of posterior MPOA (Figs. 1D, 2D). These neurons, which numbered approximately 45 per section, were located between the level at which the fornix and stria medullaris separate and the anterior border of the suprachiasmatic nucleus. At these levels, TH-IR neurons spanned the dorsoventral extent of the lateral MPOA. A few TH-IR neurons were also observed in the medial preoptic nucleus and in the lateral preoptic area. In other forebrain regions, the distribution and numbers of TH-IR neurons were identical to that described previously in noncolchicinetreated hamsters (Vincent, '88).

In addition to the previously described dopamine-IR cells in $\mathrm{MeP}$ (Asmus et al., '92), dopamine-IR neurons were observed in the BNSTpm of colchicine-treated hamsters at the same level as the TH-IR cell group in this region (data not shown). However, no dopamine-immunostained cells were seen in the MPOA other than the classically described periventricular neurons (Hökfelt et al., '84).

\section{TH and AR colocalization in Me, BNST, and MPOA}

The distribution of AR immunostaining was similar to that described in studies utilizing steroid autoradiography (Doherty and Sheridan, '81; Wood et al., '92) or AR immunocytochemistry (Wood and Newman, '93a). The brain regions with the highest concentrations of AR-IR cell nuclei were the lateral septum, BNST, MPOA, corticomedial amygdala, and hypothalamus. Colchicine administration did not alter the pattern of AR immunostaining, and a comparison of the number of AR-IR cells in Me and BNST, areas in which colchicine enhanced TH immunostaining, revealed no significant differences between colchicine- and noncolchicine-treated hamsters (data not shown).

In addition, sequential immunostaining for $\mathrm{AR}$ and $\mathrm{TH}$ did not affect the pattern of labeling for either of these antigens compared with tissues that had been stained for only a single antigen. In double-immunostained tissues, numerous neurons were immunoreactive for both $\mathrm{TH}$ (reddish-brown cytoplasm) and AR (black nucleus) (Fig. $3 \mathrm{~A}-\mathrm{C}$ ). Neurons immunostained for $\mathrm{AR}$ or $\mathrm{TH}$ alone were also observed in the same sections as double-labeled neu- 
rons (Fig. 3D). The vast majority of AR-IR cells did not contain TH. In general, areas that contained TH-IR neurons and a high density of AR-IR neurons also exhibited a high percentage of colocalization.

To determine the extent of colocalization, counts were made from colchicine-treated brains. Anterior levels of the amygdala contained AR-IR cells scattered throughout the corticomedial region. In MeA, an average of $33 \%$ of the TH-IR neurons contained AR (Figs. 2A, 3D, 4). The posterior amygdala contained a high density of AR-IR cells, predominantly in $\mathrm{MeP}$ and the amygdalohippocampal area, and in MeP, $74 \%$ of the TH-IR neurons contained AR (Figs. $2 \mathrm{~B}, 3 \mathrm{~A}, \mathrm{~B}, 4)$. Androgen receptor-containing cells were present throughout the subdivisions of the BNST, with the highest concentration in BNSTpm, where an average of $79 \%$ of the TH-IR neurons contained AR (Figs. 2C, 3C, 4). The extent of colocalization in the BNSTpm was significantly greater than that in MeA but not different from that in MeP (Fig. 4). No double-labeled cells were seen in the BNSTpl, which possessed only a limited number of either TH- or AR-IR cells (Fig. 2C). The MPOA contained numerous AR-IR cells, primarily in the medial region. Immunolabeled nuclei formed a continuous band extending from the medial preoptic nucleus dorsoventrally to the preoptic extension of the BNSTpm (Fig. 2C,D). However, the majority of TH-IR neurons were present in the lateral region of the MPOA, and only $4 \%$ of these neurons contained AR (Figs. 2D, 4). In spite of the fewer number of TH-IR neurons in noncolchicine-treated brains, colocalization of TH and AR was also observed in the BNSTpm and MeP of these brains.

\section{Effects of castration on TH immunoreactivity}

In castrated hamsters that received $\mathrm{T}$ implants, the lengths of the androgen-sensitive flank glands (Giegel et al., '71) were not significantly different from those of intact animals at any time after castration, indicating that the capsules were effectively releasing $T$. However, the flank glands of castrated hamsters without steroid replacement were significantly smaller than those in intact and T-replaced, castrated hamsters at all postcastration intervals (data not shown). Gross observation revealed that castration greatly reduced seminal vesicle size, and this effect was reversed by $\mathrm{T}$ replacement.

Analysis of MeA, MeP, BNSTpm, and MPOA at four times after castration revealed a substantial, yet transient, decrease in TH immunostaining only in MeA, while the number of TH-IR neurons in MeA of intact hamsters did not vary over time (Fig. 5). Four and 6 weeks after orchidectomy, the mean number of TH-IR neurons per section in MeA of castrated hamsters was significantly less than that of intact animals (Figs. 5, 6A). This effect was maximal 6 weeks after castration, at which time the number of immunolabeled neurons was $39 \%$ that of intact values. However, 12 weeks after castration, TH immunostaining in MeA did not differ significantly between castrated and intact animals (Figs. 5, 6B). The number of TH-IR neurons in MeA of T-replaced, castrated hamsters was not significantly different from that of intact or castrated animals at any time point and did not vary significantly over time (Fig. 5).

In $\mathrm{MeP}$, no significant differences in $\mathrm{TH}$ immunostaining were observed between castrated, castrated plus $\mathrm{T}$, and intact hamsters at any of the time points examined (Fig. 7A). Furthermore, castration for 6 or 12 weeks did not alter the number of TH-IR neurons in the BNSTpm or the lateral MPOA (Fig. 7B,C).

\section{DISCUSSION}

Although immunostaining for estrogen and progestin receptors has been colocalized with several neurotransmitters or transmitter-synthesizing enzymes (Blaustein and Turcotte, '89; Axelson and van Leeuwen, '90; Herbison and Theodosis, '91; Warembourg and Poulain, '91; Axelson et al., '92; Kohama et al., '92), and the distribution of AR-IR cell nuclei has been described in the mammalian (Sar et al., '90; Clancy et al., '92; Wood and Newman, '93a) and avian (Balthazart et al., '92) brain, this study provides direct evidence for AR immunoreactivity in a specific, chemically defined group of neurons. Furthermore, three of the TH-IR cell groups in which these receptors are described (MeA, $\mathrm{MeP}$, and BNSTpm) are outside the classically defined catecholamine systems (Hökfelt et al., '84) and may be unique to the Syrian hamster.

The Syrian hamster is the only species in which TH-IR neurons have been described in Me (Davis and Macrides, '83; Vincent, '88; Asmus et al., '92). To our knowledge, the TH-IR cells in the BNSTpm are also species-specific. In the rat, Hökfelt et al. ('84) reported TH-IR neurons only in the rostral, ventral BNST, ventral to the body of the anterior commissure. These neurons were classified as part of the dorsal component of the A15 dopamine cell group and were described as continuous medially with the A14 periventricular neurons at more caudal levels. Additionally, cells in the lateral part of the posterior BNST in the rat express TH during development, but the number of these cells decreases in the adult (Verney et al., '88; Mezey, '89). No reports have shown TH-synthesizing neurons in the encapsulated region of the rat BNST, equivalent to the hamster BNSTpm. In contrast, the TH-IR cells described in the posterior, lateral MPOA appear to correspond to the ventral component of the A15 cell group observed in the rat MPOA (see Fig. 40 in Hökfelt et al., '84).

Visualization of the three species-specific TH-IR cell groups (MeA, MeP, and BNSTpm) required the administration of colchicine, which has been widely used as an axoplasmic transport inhibitor (Dahlstrom, '68) to enhance immunostaining for various neurotransmitters and related synthetic enzymes, including TH (Simerly et al., '85; Kitahama et al., '89; Kitahama et al., '90; Asmus et al., '92). However, several reports indicate that colchicine treatment may alter the mRNA levels for several neuropeptides (Cortes et al., '90; Ceccatelli et al., '91; Kiyama and Emson, '91; Rethelyi et al., '91) and transmitter-synthesizing enzymes (Cortes et al., '90) in specific brain regions. Thus, it is possible that colchicine administration may have induced or increased the expression of TH mRNA in the TH-IR cell groups reported here, leading to false positivity. On the other hand, previous reports from other laboratories (Davis and Macrides, '83; Vincent, '88) as well as our own (Asmus et al., '92) have shown that, although fewer in number, TH-IR neurons are present in Me of noncolchicine-treated hamsters. Furthermore, in situ hybridization studies of $\mathrm{Me}$ in our laboratory with a radiolabeled, complimentary RNA probe have demonstrated TH mRNA-containing cells in both $\mathrm{MeA}$ and MeP of noncolchicine-treated hamsters (unpublished observations). After correcting for differences in section thickness, the distribution and number of TH mRNAcontaining cells in these brain regions are similar to those 

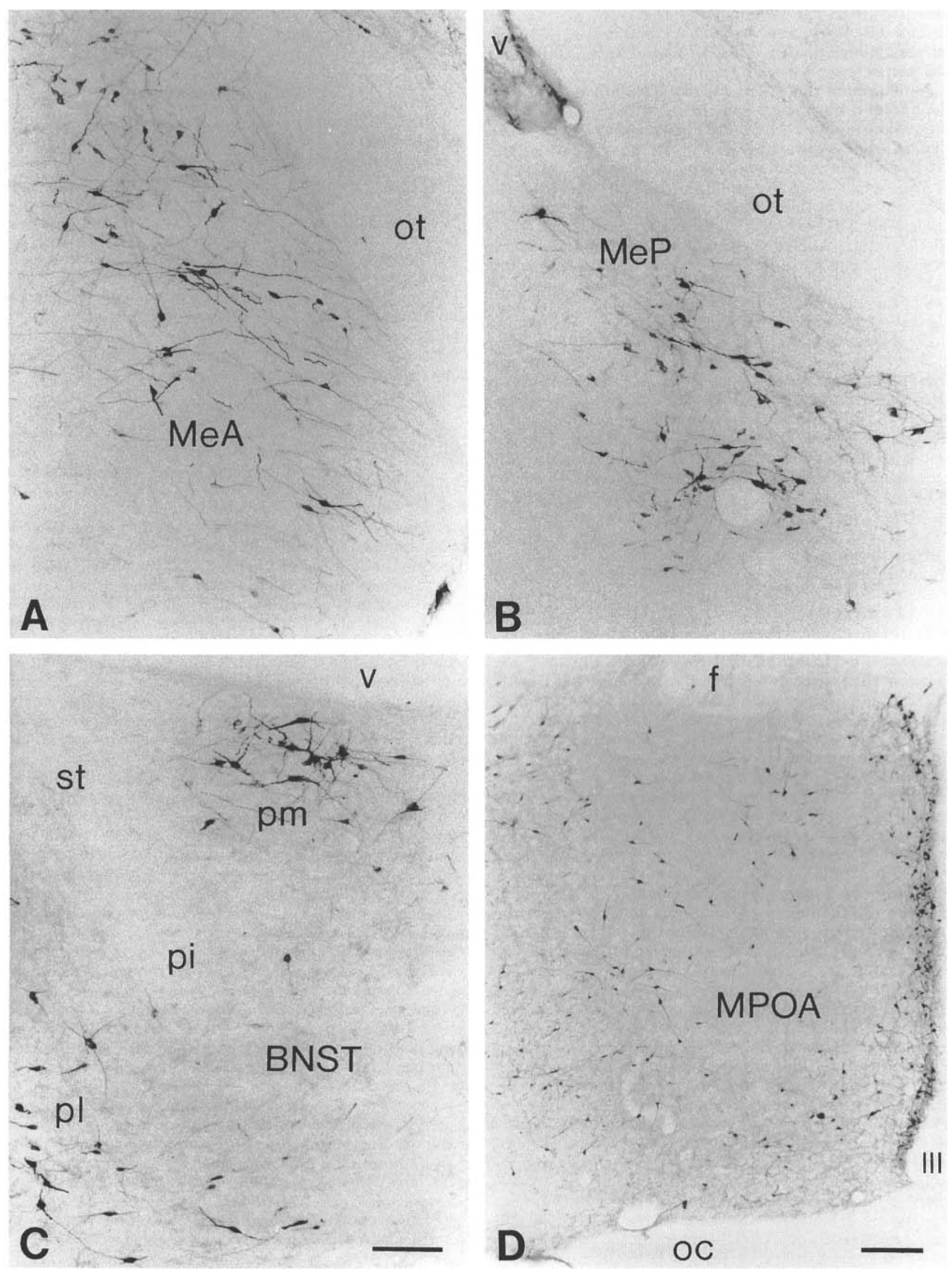


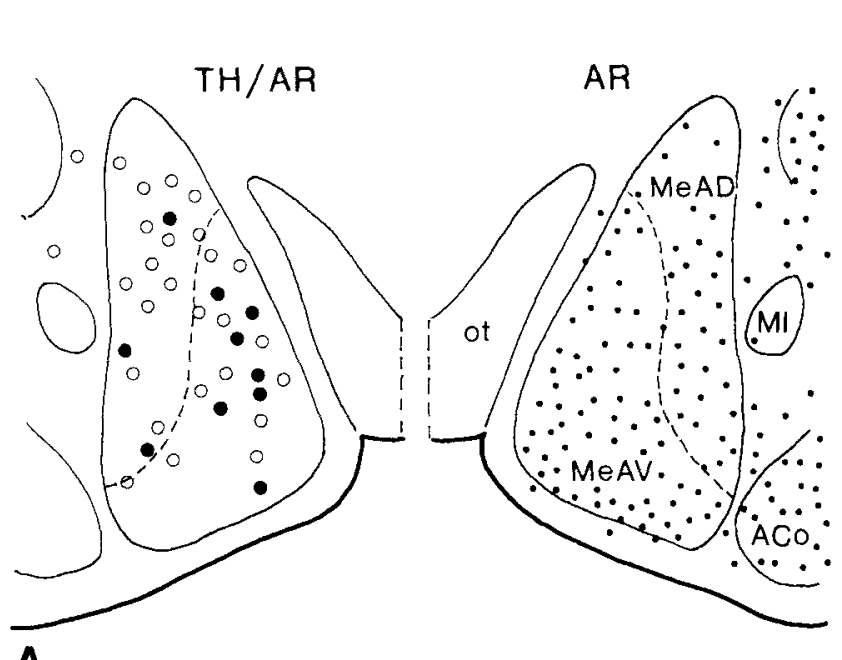

A
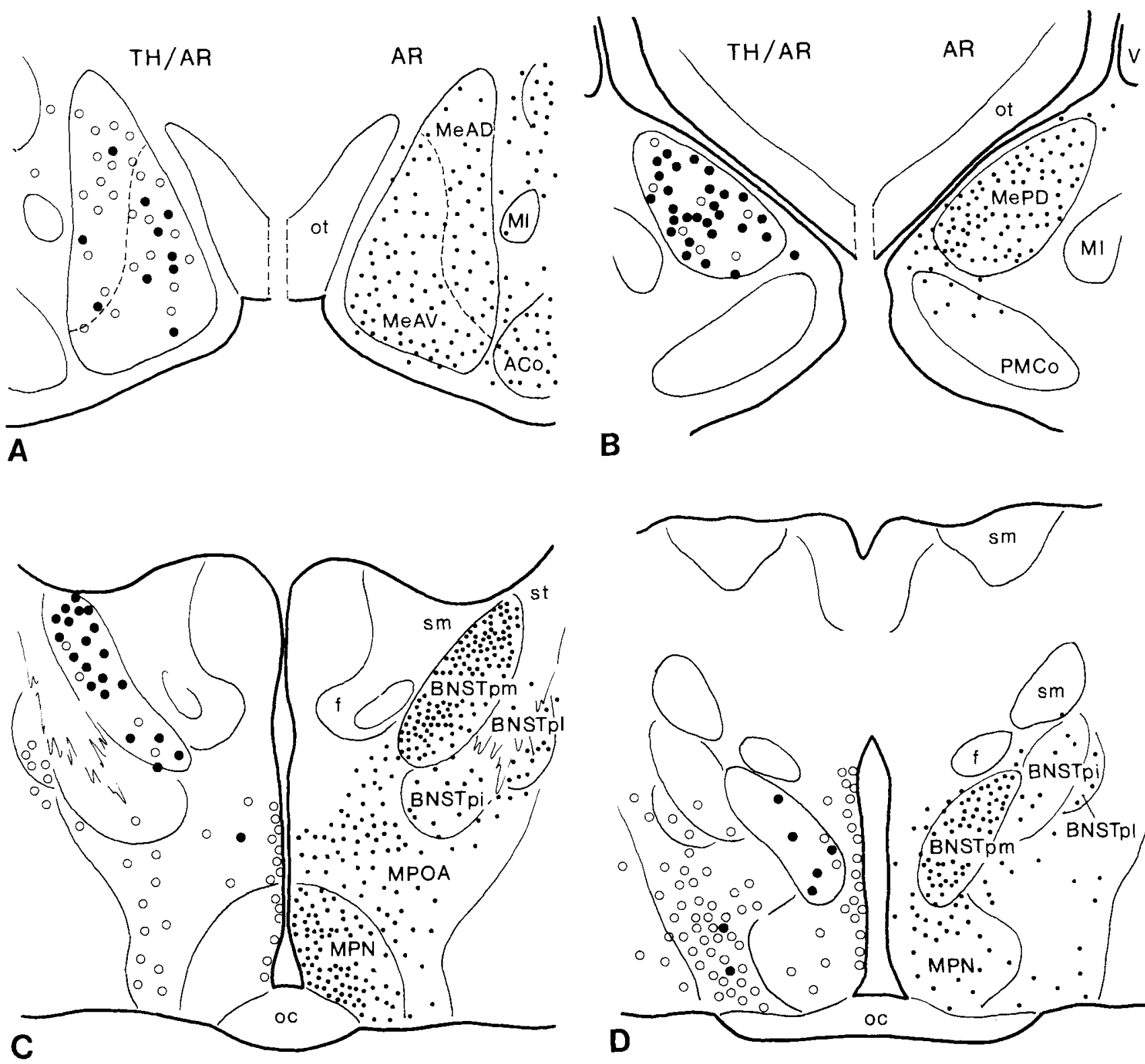

Fig. 2. Camera lucida tracings of coronal sections through MeA (A), MeP (B), BNST, and MPOA (C,D) of an individual animal. The left side of each drawing shows the distribution of TH-IR neurons (open circles) and cells double-labeled for both TH and AR (closed circles). Each circle

of the TH-IR neurons in colchicine-treated brains reported here. These findings support our interpretation that colchicine inhibits the axoplasmic transport of $\mathrm{TH}$, allowing its immunocytochemical detection. In addition, it is unlikely that colchicine caused widespread cell death in the chemosensory pathway. Zolovick et al. ('80) reported that injections of colchicine directly into the rat $\mathrm{Me}$, while

Fig. 1. Photomicrographs of TH-IR neurons in $\mathrm{MeA}(\mathbf{A}), \mathrm{MeP}(\mathbf{B})$, BNST (C), and MPOA (D). The rostro-caudal level of each of these areas corresponds to that in the tracing of the same letter in Figure 2. Scale bar $=100 \mu \mathrm{m}$ for A-C; $200 \mu \mathrm{m}$ for D.

reversibly disrupting sodium appetite, only produced cytological damage comparable to that of saline injections.

The lack of immunostaining for DBH and PNMT in all of the regions discussed above in both colchicine- (Asmus et al., '92) and noncolchicine-treated (Vincent, '88) hamster brains suggests that the forebrain TH-IR neurons described here do not produce norepinephrine or epinephrine. Dopamine-IR neurons were observed in the BNSTpm in the present study and in $\mathrm{MeP}$ in the present and previous studies (Asmus et al., '92), suggesting that the speciesspecific TH-IR neurons in these regions are dopaminergic. However, no dopamine-IR neurons were observed in the MPOA in the present study or in MeA here or in the 

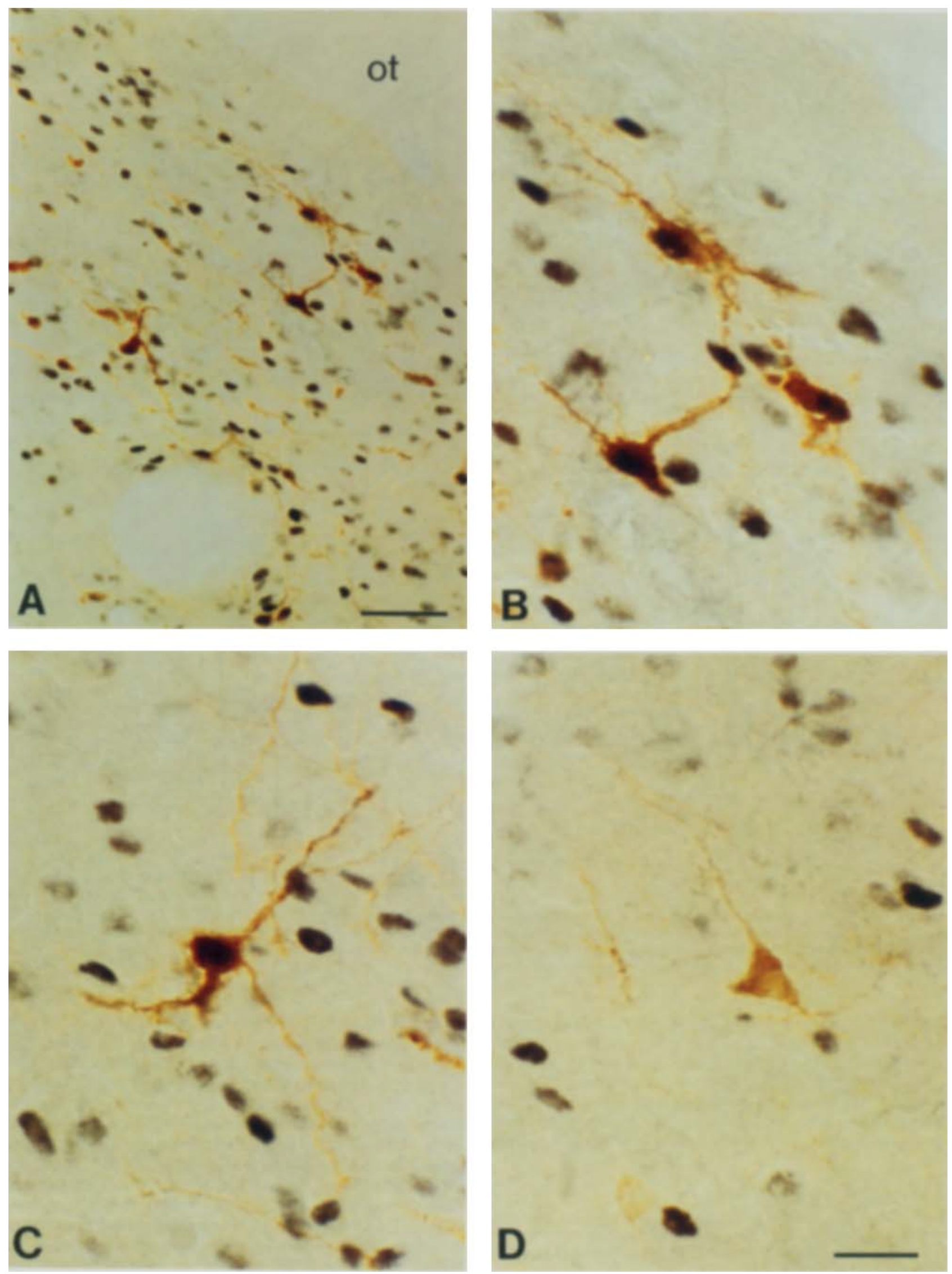


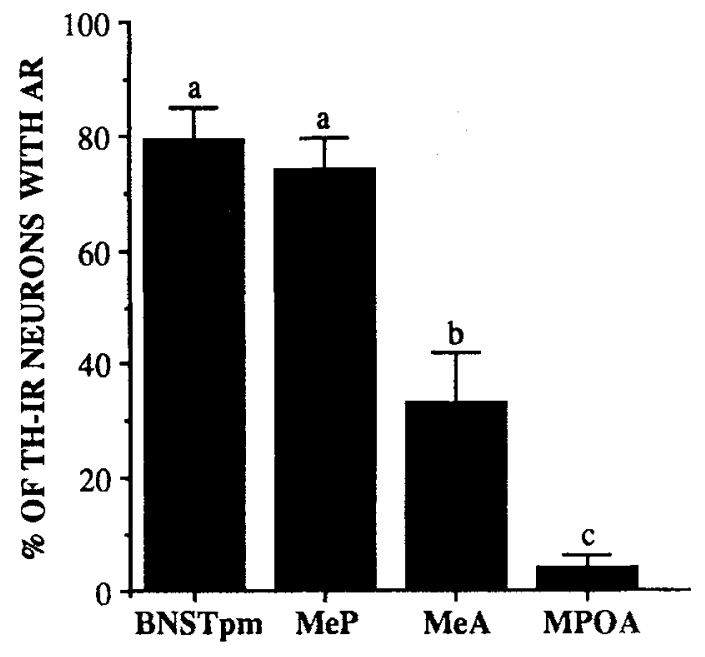

Fig. 4. Mean percentage $( \pm$ SEM) of TH-IR neurons containing AR-IR cell nuclei in specific subdivisions of the chemosensory pathway. Bars with different superscripts are significantly different $(P<0.05)$

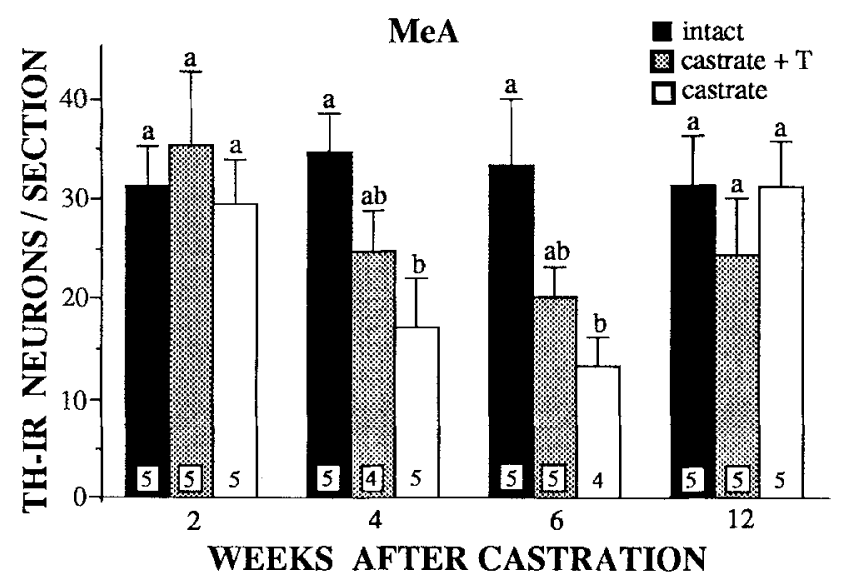

Fig. 5. Mean number ( \pm SEM) of TH-IR neurons per $40 \mu \mathrm{m}$ section through $\mathrm{MeA}$ at specific times after castration. Within each time period, bars with different superscripts are significantly different $(P<0.05)$ The number within each bar represents the number of animals.

previous report (Asmus et al., '92). Thus, the TH-IR neurons in the MPOA and MeA may either produce quantities of dopamine that are below the level of detection with the present immunocytochemical technique, or they may synthesize only the immediate precursor of dopamine, L-DOPA, a neurotransmitter candidate. L-DOPA is reported to be an endproduct in some TH-IR cells that lack the enzyme aromatic amino acid decarboxylase (AADC), which converts L-DOPA to dopamine (Meister et al., '88; Okamura et al., '88; Kitahama et al., '90; Vincent and Hope,

Fig. 3. Photomicrographs of TH-IR neurons (reddish-brown cytoplasmic staining), AR-IR cells (black nuclear staining), and doublelabeled cells. A: Cells single-labeled for AR and double-labeled for TH and $\mathrm{AR}$ are present in MeP. B: Higher magnification of double-labeled neurons that are shown in A. C: Double-labeled neuron in BNSTpm. D: Single-labeled TH-IR neuron in MeA. Scale bar $=50 \mu \mathrm{m}$ for A, $20 \mu \mathrm{m}$ for B-D.
'90; Mons et al., '91), and L-DOPA is released in a neurotransmitter-like fashion (Goshima et al., '88; Nakamura et al., '92). Because the presently available antisera against AADC have not produced satisfactory immunostaining in our hands, we are currently unable to provide evidence as to whether the TH-IR neurons in the MPOA and MeA synthesize AADC. This issue awaits further study.

The distribution of the four specific TH-IR cell groups in $\mathrm{MeA}, \mathrm{MeP}, \mathrm{BNSTpm}$, and MPOA is particularly interesting in view of the differences in functions and connections of these four subnuclei in the chemosensory pathway. Both gonadal hormones (Beach and Pauker, '49; Whalen and DeBold, '74; Morin and Zucker, '78; Lisk and Bezier, '80; Powers et al., '85) and chemosensory stimulation (Murphy and Schneider, '70; Devor, '73; Powers and Winans, '75) are essential for mating behavior in the male hamster, and the presence of gonadal steroid-accumulating neurons in the chemosensory pathway has been well established (Krieger et al., '76; Doherty and Sheridan, '81; Wood et al., '92). Within this pathway, however, connections of the nuclear subdivisions suggest that there may be distinguishable "chemosensory" and "hormonal" circuits (Gomez and Newman, '92). For example, MeA, which receives substantial vomeronasal and olfactory input (Kevetter and Winans, '81; Lehman and Winans, '82) and contains only a moderate number of steroid-concentrating cells (Wood et al., '92), projects specifically to the BNSTpi and to the lateral part of the MPOA (Gomez and Newman, '92). Conversely, MeP, which is densely populated with steroid-concentrating cells (Krieger et al., '76; Doherty and Sheridan, '81; Wood et al., '92) and receives only a small, direct vomeronasal input (Lehman and Winans, '82), projects to the BNSTpm and to the medial part of the MPOA (Gomez and Newman, '92), both of which contain substantially more steroid-accumulating cells than the adjacent lateral regions (Wood et al., '92). Therefore, regions receiving direct chemosensory input are linked anatomically with each other while the same is true for predominantly steroid-concentrating regions. Additionally, lesions of anterior (Lehman et al., '80; Lehman and Winans, '82), but not posterior (Lehman et al., '83), Me in the male hamster completely eliminate mating behavior and severely reduce chemoinvestigatory behavior.

The data presented here suggest that the chemosensory and hormonal parts of this pathway may also differ neurochemically. The chemosensory regions that contained TH-IR neurons, MeA and lateral MPOA, lacked dopamine-IR cells, suggesting that these neurons may either produce relatively low amounts of dopamine or they may produce L-DOPA as an endproduct, while the subdivisions of the hormonal circuit, $\mathrm{MeP}$ and BNSTpm, displayed dopamine immunoreactivity.

As expected, regions previously shown to have the highest density of gonadal steroid-accumulating cells displayed the greatest percentage of $\mathrm{TH}$ and $\mathrm{AR}$ colocalization. At least three-fourths of the TH-IR neurons in MeP and BNSTpm contained AR, indicating that the majority of TH-IR neurons in these areas can directly receive hormonal information. We hypothesized, therefore, that castration would influence $\mathrm{TH}$ production in these neurons. However, the results of this experiment demonstrated that immunostainable levels of TH in these regions were not altered after castration, suggesting that TH synthesis in these cells may not be directly regulated by AR. Although subtle changes in $\mathrm{TH}$ levels may not have been detected with immunocytochemistry, these results suggest that gonadal 

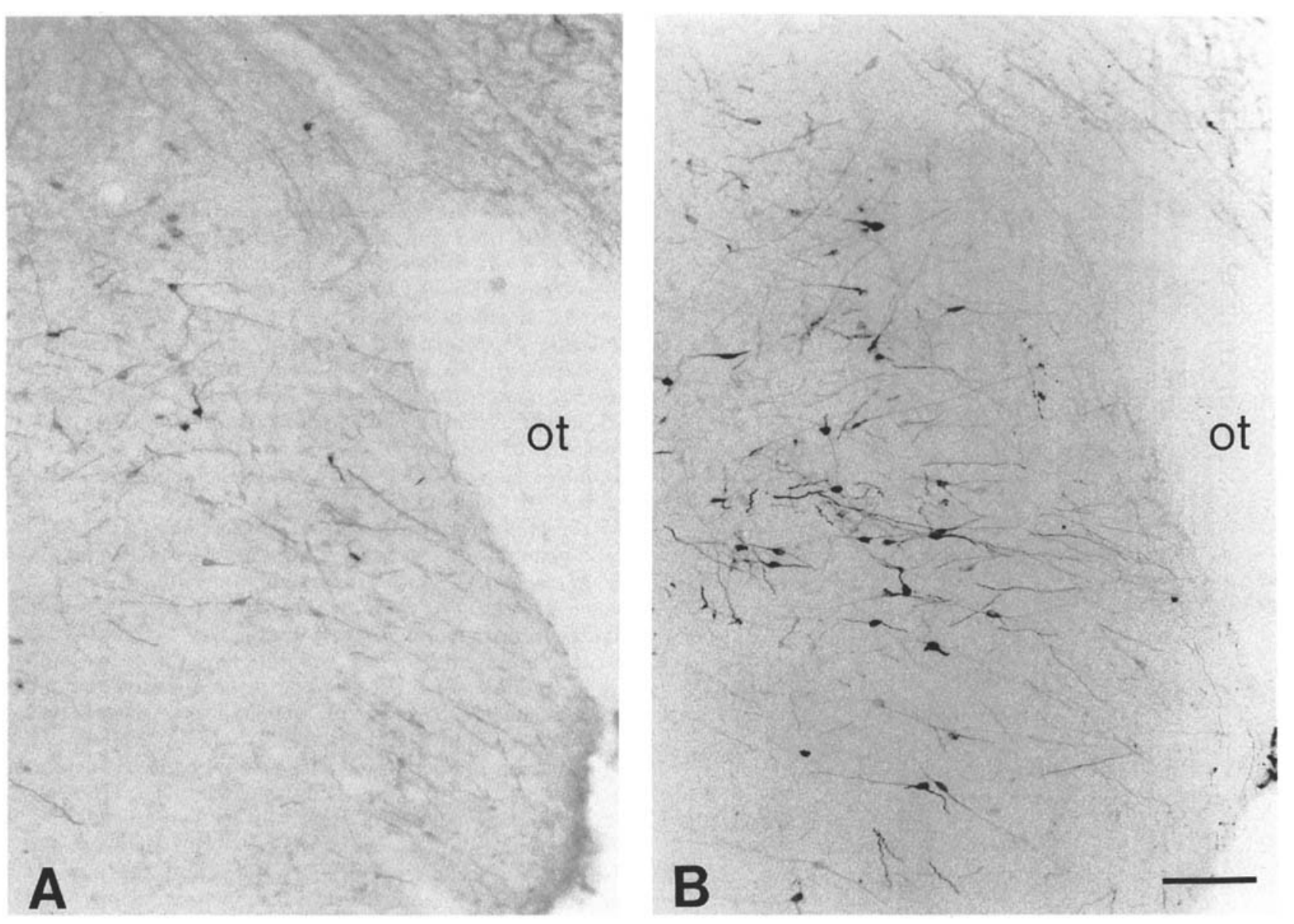

Fig. 6. Photomicrographs of TH immunostaining in MeA 6 (A) and 12 (B) weeks after castration. Scale bar $=100 \mu \mathrm{m}$ for A and B.

hormones regulate other genes in addition to, or instead of, the TH gene in these cells.

In contrast, fewer TH-IR neurons in the "chemosensory circuit," MeA and lateral MPOA, contained AR, but removal of gonadal hormones for 4 to 6 weeks resulted in a dramatic decrease in the number of TH-IR neurons in MeA. This demonstration of hormonal influences on neurons in the hamster MeA is surprising, because this area has relatively fewer gonadal steroid-accumulating cells than other steroid-accumulating regions (Wood et al., '92), and previous castration-induced effects in the hamster and rat have been observed only in areas of this pathway that contain abundant steroid receptors, including MeP, BNSTpm, and medial MPOA (Simerly and Swanson, '87; Simerly, '90; Gomez and Newman, '91; Swann and Newman, '92). The previously reported evidence that MeA receives substantial chemosensory input (Kevetter and Winans, '81; Lehman and Winans, ' 82 ) and the data presented here, that MeA responds to changes in gonadal hormone levels, support the interpretation of lesion studies (Lehman et al., '80; Lehman and Winans, ' 82 ) that this specific brain region integrates chemosensory and hormonal information essential for mating behavior in the male hamster.

Although the present study did not address potential transcriptional and/or translational modifications of TH production, we interpret the decrease in the number of
TH-IR neurons in MeA to reflect a decrease in TH synthesis. Gonadal steroids have been shown to regulate $\mathrm{TH}$ mRNA and protein synthesis in other brain regions (Morrell et al., '89; Simerly, '89; Pasqualini et al., '91; Sanghera et al., '91; Liaw et al., '92). Additionally, colchicine treatment of all experimental groups presumably negated any castration-induced effects on axonal transport.

Because one-third of the TH-IR neurons in MeA contained AR, some of the decrease in TH immunostaining following castration may be a direct result of the loss of androgenic stimulation of $\mathrm{TH}$ gene expression. However, castration resulted in the loss of $61 \%$ of the TH-IR neurons. Thus, it seems likely that at least some, and perhaps all, of the TH-IR neurons in MeA that did not contain AR were influenced by castration. Determining whether the TH-IR neurons remaining in 4- and 6-week castrated hamsters contain AR is difficult, because orchidectomy decreases the intensity of $\mathrm{AR}$ immunostaining and shifts the receptor immunoreactivity from a nuclear to a predominantly cytoplasmic domain (Wood and Newman, '93b). Thus, colocalization of cytoplasmic $\mathrm{AR}$ and $\mathrm{TH}$ is impossible with the double immunoperoxidase technique used here and will be addressed in future studies.

As an alternative explanation to that of direct androgenic stimulation of $\mathrm{TH}$ gene expression, the neurons in MeA 


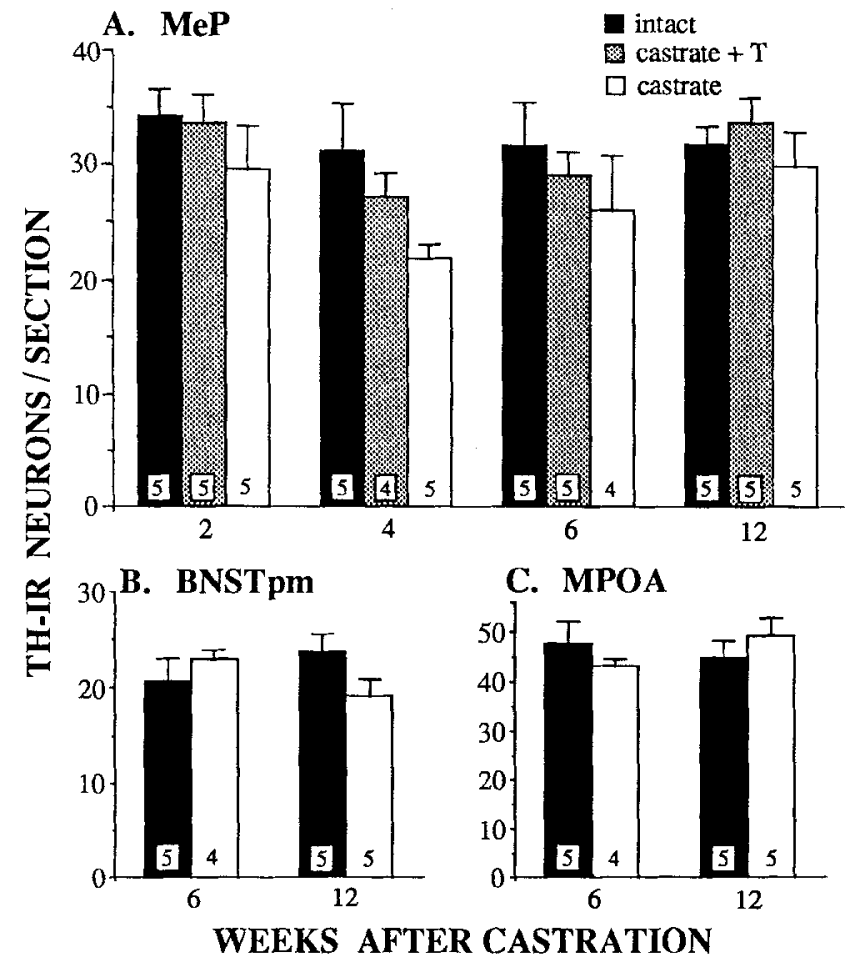

Fig. 7. Mean number ( \pm SEM) of TH-IR neurons per $40 \mu \mathrm{m}$ section through MeP (A), BNSTpm (B), and MPOA (C) at specific times after castration. No significant differences were found between any of the groups at any time after castration. The number within each bar represents the number of animals.

that lose their TH immunostaining may be affected directly by hormonal metabolites of testosterone or indirectly by synaptic input. Direct hormonal effects might be mediated through estrogen receptors in the TH-IR neurons in MeA. The hamster Me contains aromatase (Hutchison et al., '91) as well as estrogen receptors (Krieger et al., '76; Wood et al., '92). Thus, TH-IR neurons in MeA could be influenced by castration through the loss of estradiol provided by aromatization of testosterone, although, like AR, the highest density of estrogen receptors is found in $\mathrm{MeP}$ (Wood et al., '92). Alternatively, TH synthesis in MeA might be regulated by synaptic input (Zigmond, ' 85 ; Kilbourne et al., '92) from steroid receptor-containing cells located in this or other brain areas.

Surprisingly, the number of TH-IR neurons in MeA returned to intact values 12 weeks after castration, suggesting that the decrease in TH immunostaining observed 4 and 6 weeks after castration was not due to cell death. This transient effect, although unusual, is not unprecedented. Almeida et al. ('92) reported that hypothalamic $\beta$-endorphin levels were significantly altered 1 week after castration but returned to control values 4 weeks after gonadectomy. One possible explanation for the return of $\mathrm{TH}$ immunostaining in $\mathrm{MeA}$ is that reorganization of synaptic input may occur after long periods of hormone withdrawal. According to this hypothesis, the initial response to castration might be due to the loss of synaptic input from steroid receptor-containing cells onto the TH-IR neurons, followed by the establishment of novel connections from steroidindependent neurons. This reinnervation could provide input to the TH-IR neurons sufficient to drive TH produc- tion. Synaptic reorganization in the adult brain in response to gonadal steroid manipulation has been well documented (Arnold, '90; Matsumoto,'91).

Because mating behavior is essentially lost 12 weeks after castration (Morin and Zucker, '78) when TH immunostaining has returned to normal, it would appear that the TH-IR neurons in MeA are not crucial to mating. However, if, as hypothesized above, hormone-independent synaptic activity from newly formed connections reinstates TH production in MeA in long-term castrates, this input may not be properly coding information relevant to mating behavior. In this case, although TH immunostaining appears normal, these neurons may no longer be receiving and transmitting the signals necessary for mating to occur.

At present, the function of the TH-IR neurons in the chemosensory pathway is unknown. Although they may be involved in circuits underlying nonreproductive functions such as salt intake (Schulkin et al, '89) and aggression (Vochteloo and Koolhaas, '87), the data presented here indicate that specific subgroups of these cells contain AR and that the majority of TH-IR cells in MeA are influenced by gonadal hormones. Thus, as a population, the TH-IR neurons in this pathway may be involved in the processing of hormonal signals that are required for male hamster chemoinvestigation (Powers et al., '85) and copulation (Beach and Pauker, '49; Whalen and DeBold, '74; Morin and Zucker, '78; Lisk and Bezier, '80; Powers et al., '85).

\section{ACKNOWLEDGMENTS}

The authors thank Dr. Gail S. Prins of the University of Illinois College of Medicine for the AR antiserum, Dr. Ruth I. Wood and Ms. Sara S. Kollack for their critical reading of the manuscript, and Ms. Lorita Dudus and Ms. R. Kaye Brabec of the Morphology Core of the Center for the Study of Reproduction at the University of Michigan for their valuable technical assistance, supported by 1-P30-HD18258. This work was supported by NIH grant NS20629 to S.W.N.

\section{LITERATURE CITED}

Almeida, O.F.X., A.H.S. Hassan, M.S. Harbuz, E.A. Linton, and S.L Lightman (1992) Hypothalamic corticotropin-releasing hormone and opioid peptide neurons: Functional changes after adrenalectomy and/or castration. Brain Res. 571:189-198.

Arnold, A.P. (1990) Hormonally induced synaptic reorganization in the adult brain. In J. Balthazart (ed): Hormones, Brain and Behavior in Vertebrates. 1. Sexual Differentiation, Neuroanatomical Aspects, Neurotransmitters and Neuropeptides. Comp. Physiol. Vol. 8. Basel: Karger, pp. 82-91.

Asmus, S.E., A.E. Kincaid, and S.W. Newman (1992) A species-specific population of tyrosine hydroxylase-immunoreactive neurons in the medial amygdaloid nucleus of the Syrian hamster. Brain Res. 575:199207

Axelson, J.F., and F.W. van Leeuwen (1990) Differential localization of estrogen receptors in various vasopressin synthesizing nuclei of the rat brain. J. Neuroendocrinol. 2:209-216.

Axelson, J.F., W. Shannon, and F.W. van Leeuwen (1992) Immunocytochemical localization of estrogen receptors within neurotensin cells in the rostral preoptic area of the rat hypothalamus. Neurosei. Lett. 136:5-9.

Balthazart, J., A. Foidart, E.M. Wilson, and G.F. Ball (1992) Immunocytochemical localization of androgen receptors in the male songbird and quail brain. J. Comp. Neurol. 317:407-420.

Beach, F.A., and R.S. Pauker (1949) Effects of castration and subsequent androgen administration upon mating behavior in the male hamster (Cricetus auratus). Endocrinology 45:211-221.

Blaustein, J.D., and J.C. Turcotte (1989) A small population of tyrosine hydroxylase-immunoreactive neurons in the guinea-pig arcuate nucleus 
contains progestin receptor-immunoreactivity. J. Neuroendocrinol. 1:333-338.

Campbell, C.S., J.S. Finkelstein, and F.W. Turek (1978) The interaction of photoperiod and testosterone on the development of copulatory behavior in castrated male hamsters. Physiol. Behav. 21:409-415.

Ceccatelli, S., R. Cortes, and T. Hokfelt (1991) Effect of reserpine and colchicine on neuropeptide $\mathrm{mRNA}$ levels in the rat hypothalamic paraventricular nucleus. Mol. Brain Res. 9:57-69.

Clancy, A.N., R.W. Bonsall, and R.P. Michael (1992) Immunohistochemical labeling of androgen receptors in the brain of rat and monkey. Life Sci. 50:409-417.

Cortes, R., S. Ceccatelli, M. Schalling, and T. Hokfelt (1990) Differential effects of intracerebroventricular colchicine administration on the expression of mRNAs for neuropeptides and neurotransmitter enzymes, with special emphasis on galanin: An in situ hybridization study. Synapse 6:369-391.

Dahlstrom, A. (1968) Effect of colchicine on transport of amine storage granules in sympathetic nerves of rat. Eur. J. Pharmacol. 5:111-113.

Davis, B.J., and F.M. Macrides (1983) Tyrosine hydroxylase immunoreactive neurons and fibers in the olfactory system of the hamster. J. Comp. Neurol. 214:427-440.

Devor, M. (1973) Components of mating dissociated by lateral olfactory tract transection in male hamsters. Brain Res. 64:437-441.

Doherty, P.C., and P.J. Sheridan (1981) Uptake and retention of androgen in neurons of the brain of the golden hamster. Brain Res. 219:327-334.

Giegel, J.L., L.M. Stolfi, G.D. Weinstein, and P. Frost (1971) Androgenic regulation of nucleic acid and protein synthesis in the hamster flank organ and other tissues. Endocrinology 89:904-909.

Gomez, D.M., and S.W. Newman (1991) Medial nucleus of the amygdala in the adult Syrian hanster: A quantitative Golgi analysis of gonadal hormonal regulation of neuronal morphology. Anat. Rec. 231:498-509.

Gomez, D.M., and S.W. Newman (1992) Differential projections of the anterior and posterior regions of the medial amygdaloid nucleus in the Syrian hamster. J. Comp. Neurol. 317:195-218.

Goshima, Y., T. Kubo, and Y. Misu (1988) Transmitter-like release of endogenous 3,4-dihydroxyphenylalanine from rat striatal slices. J. Neurochem. 50:1725-1730.

Herbison, A.E., and D.T. Theodosis (1991) Neurotensin-immunoreactive neurons in the rat medial preoptic area are oestrogen-receptive. J. Neuroendocrinol. 3:587-589.

Hökfelt, T., R. Martensson, A. Björklund, S. Kleinau, and M. Goldstein (1984) Distributional maps of tyrosine-hydroxylase-immunoreactive neurons in the rat brain. In A. Björklund and T. Hökfelt (eds): Handbook of Chemical Neuroanatomy, Vol. 2, Classical Transmitters in the CNS, Part I. Amsterdam: Elsevier, pp. 277-379.

Hutchison, R.E., J.B. Hutchison, T. Steimer, E. Steel, J.B. Powers, A.P. Walker, J. Herbert, and M.H. Hastings (1991) Brain aromatization of testosterone in the male Syrian hamster: Effects of androgen and photoperiod. Neuroendocrinology 53:194-203.

Kendrick, K.M., and R.F. Drewett (1979) Testosterone reduces refractory period of stria terminalis neurons in the rat brain. Science 204:877-879.

Kevetter, G.A., and S.S. Winans (1981) Connections of the corticomedial amygdala in the golden hamster. II. Efferents of the "olfactory amygdala." J. Comp. Neurol. 197:99-111.

Kilbourne, E.J., B.B. Nankova, E.J. Lewis, A. McMahon, H. Osaka, D.B. Sabban, and E.L. Sabban (1992) Regulated expression of the tyrosine hydroxylase gene by membrane depolarization: Identification of the responsive element and possible second messengers. J. Biol. Chem. 267:7563-7569.

Kitahama, K., H. Okamura, M. Goldstein, I. Nagatsu, A. Berod, and M. Jouvet (1989) A new group of tyrosine hydroxylase-immunoreactive neurons in the cat thalamus. Brain Res. 478:156-160.

Kitahama, K., M. Geffard, H. Okamura, I. Nagatsu, N. Mons, and M. Jouvet (1990) Dopamine- and DOPA-immunoreactive neurons in the cat forebrain with reference to tyrosine hydroxylase-immunohistochemistry. Brain Res. 518:83-94

Kiyama, H., and P.C. Emson (1991) Colchicine-induced expression of proneurotensin mRNA in rat striatum and hypothalamus. Mol. Brain Res. 9:353-358.

Kohama, S.G., F. Freesh, and C.L. Bethea (1992) Immunocytochemical colocalization of hypothalamic progestin receptors and tyrosine hydroxylase in steroid-treated monkeys. Endocrinology 131:509-517.

Kollack, S.S., and S.W. Newman (1992) Mating behavior induces selective expression of Fos protein within the chemosensory pathways of the male Syrian hamster brain. Neurosci. Lett. 143:223-228.
Krieger, M.S., J.I. Morrell, and D.W. Pfaff (1976) Autoradiographic localization of estradiol-concentrating cells in the female hamster brain. Neuroendocrinology 22:193-205.

Kubo, T., J.-L. Yue, Y. Goshima, S. Nakamura, and Y. Misu (1992) Evidence for L-DOPA systems responsible for cardiovascular control in the nucleus tractus solitarii of the rat. Neurosci. Lett. 140:153-156.

Lehman, M.N., and S.S. Winans (1982) Vomeronasal and olfactory pathways to the amygdala controlling male hamster sexual behavior: Autoradiographic and behavioral analyses. Brain Res. 240:27-41.

Lehman, M.N., S.S. Winans, and J.B. Powers (1980) Medial nucleus of the amygdala mediates chemosensory control of male hamster sexual behavior. Seience $210: 557-560$.

Lehman, M.N., J.B. Powers, and S.S. Winans (1983) Stria terminalis lesions alter the temporal pattern of copulatory behavior in the male golden hamster. Behav. Brain Res. 8:109-128.

Liaw, J.-J., J.-R. He, R.D. Hartman, and C.A. Barraclough (1992) Changes in tyrosine hydroxylase $\mathrm{mRNA}$ levels in medullary $\mathrm{AI}$ and $\mathrm{A} 2$ neurons and locus coeruleus following castration and estrogen replacement in rats. Mol. Brain Res. 13:231-238.

Lisk, R.D., and J.L. Bezier (1980) Intrahypothalamic hormone implantation and activation of sexual behavior in the male hamster. Neuroendocrinology $30: 220-227$.

Matsumoto, A. (1991) Synaptogenic action of sex steroids in developing and adult neuroendocrine brain. Psychoneuroendocrinology 16:25-40.

Meister, B., T. Hökfelt, H.W.M. Steinbusch, G. Skagerberg, O. Lindvall, M. Geffard, T.H. Joh, A.C. Cuello, and M. Goldstein (1988) Do tyrosine hydroxylase-immunoreactive neurons in the ventrolateral arcuate nucleus produce dopamine or only L-DOPA? J. Chem. Neuroanat. 1:59-64.

Mezey, E. (1989) Phenylethanolamine $N$-methyltransferase-containing neurons in the limbic system of the young rat. Proc. Natl. Acad. Sci. USA $86: 347-351$

Mons, N., P. Dubourg, and G. Tramu (1991) Preparation and characterization of a specific antibody for the immunohistochemical detection of L-DOPA in paraformaldehyde-fixed rodent brains. Brain Res. 554:122129.

Morin, L.P., and I. Zucker (1978) Photoperiodic regulation of copulatory behavior in the male hamster. J. Endocrinol. 77:249-258

Morrell, J.I., M.F. Rosenthal, J.T. McCabe, C.A. Harrington, D.M. Chikaraishi, and D.W. Pfaff (1989) Tyrosine hydroxylase mRNA in the neurons of the tuberoinfundibular region and zona incerta examined after gonadal steroid hormone treatment. Mol. Endocrinol. 3:1426-1433.

Murphy, M., and G.E. Schneider (1970) Olfactory bulb removal eliminates mating behavior in the male golden hamster. Science 167:302-303.

Nabekura, J., Y. Oomura, T. Minami, Y. Mizuno, and A. Fukuda (1986) Mechanism of the rapid effect of $17 \beta$-estradiol on medial amygdala neurons. Science 233:226-228.

Nakamura, S., Y. Goshima, J.L. Yue, and Y. Misu (1992) Transmitter-like basal and $\mathrm{K}^{+}$-evoked release of 3,4-dihydroxyphenylalanine from the striatum in conscious rats studied by microdialysis. J. Neurochem. $58: 270-275$.

Neal, C.R, and S.W. Newman (1989) Prodynorphin peptide distribution in the forebrain of the Syrian hamster and rat: A comparative study with antisera against dynorphin $A$, dynorphin $B$, and the C-terminus of the prodynorphin precursor molecule. J. Comp. Neurol. 288:353-386.

Okamura, H., K. Kitahama, N. Mons, Y. Ibata, M. Jouvet, and M. Geffard (1988) L-DOPA-immunoreactive neurons in the rat hypothalamic tuberal region. Neurosci. Lett. 95:42-46.

Pasqualini, C., V. Leviel, B. Guibert, N. Faucon-Biguet, and B. Kerdelhue (1991) Inhibitory actions of acute estradiol treatment on the activity and quantity of tyrosine hydroxylase in the median eminence of ovariectomized rats. J. Neuroendocrinol. 3:575-580.

Pfaff, D.W., and C. Pfaffmann (1969) Olfactory and hormonal influences on the basal forebrain of the male rat. Brain Res. 15:137-156.

Powers, J.B., and S.S. Winans (1975) Vomeronasal organ: Critical role in mediating sexual behavior of the male hamster. Science 187:961-963.

Powers, J.B., M.L. Bergondy, and J.A. Matochik (1985) Male hamster sociosexual behaviors: Effects of testosterone and its metabolites. Physiol. Behav. 35:607-616.

Powers, J.B., S.W. Newman, and M.L. Bergondy (1987) MPOA and BNST lesions in male Syrian hamsters: Differential effects on copulatory and chemoinvestigatory behaviors. Behav. Brain Res. 23:181-195.

Prins, G.S., L. Birch, and G.L. Greene (1991) Androgen receptor localization in different cell types of the adult rat prostate. Endocrinology 129:31873199 . 
Rethelyi, M., N.K. Mohapatra, C.B. Metz, P. Petrusz, and P.K. Lund (1991) Colchicine enhances mRNAs encoding the precursor of calcitonin generelated peptide in brainstem motoneurons. Neuroscience 42:531-539.

Sachs, B.D., and R.L. Meisel (1988) The physiology of male sexual behavior. In E. Knobil and $J$. Neill (eds): The Physiology of Reproduction. New York: Raven Press, pp. 1393-1485.

Sanghera, M.K., S. Grady, W. Smith, D.J. Woodward, and J.C. Porter (1991) Incertohypothalamic A13 dopamine neurons: Effect of gonadal steroids on tyrosine hydroxylase. Neuroendocrinology 53:268-275.

Sar, M., D.B. Lubahn, F.S. French, and E.M. Wilson (1990) Immunohistochemical localization of the androgen receptor in rat and human tissues. Endocrinology 127:3180-3186.

Schulkin, J., J. Marini, and A.N. Epstein (1989) A role for the medial region of the amygdala in mineralocorticoid-induced salt hunger. Behav. Neurosci. 103:178-185.

Simerly, R.B. (1989) Hormonal control of the development and regulation of tyrosine hydroxylase expression within a sexually dimorphic population of dopaminergic cells in the hypothalamus. Mol. Brain. Res. 6:297-310.

Simerly, R.B. (1990) Hormonal control of neuropeptide gene expression in sexually dimorphic olfactory pathways. Trends Neurosci. 13:104-110.

Simerly, R.B., and L.W. Swanson (1986) The organization of neural inputs to the medial preoptic nucleus of the rat. J. Comp. Neurol. 246:312-342.

Simerly, R.B., and L.W. Swanson (1987) Castration reversibly alters levels of cholecystokinin immunoreactivity within cells of three interconnected sexually dimorphic forebrain nuclei in the rat. Proc. Natl. Acad. Sci. USA 84:2087-2091.

Simerly, R.B., L.W. Swanson, and R.A. Gorski (1985) The distribution of monoaminergic cells and fibers in a periventricular preoptic nucleus involved in the control of gonadotropin release: Immunohistochemical evidence for a dopaminergic sexual dimorphism. Brain Res. 330:55-64.

Swann, J.M., and S.W. Newman (1992) Testosterone regulates substance $\mathbf{P}$ within neurons of the medial nucleus of the amygdala, the bed nucleus of the stria terminalis and the medial preoptic area of the male golden hamster. Brain Res. 590:18-28.

Verney, C., P. Gaspar, A. Febvret, and B. Berger (1988) Transient tyrosine hydroxylase-like immunoreactive neurons contain somatostatin and substance $\mathbf{P}$ in the developing amygdala and bed nucleus of the stria terminalis of the rat. Dev. Brain Res. 42:45-58.
Vincent, S.R. (1988) Distributions of tyrosine hydroxylase-, dopamine- $\beta$ hydroxylase-, and phenylethanolamine- $N$-methyltransferase-immunoreactive neurons in the brain of the hamster (Mesocricetus auratus). J. Comp. Neurol. 268:584-599.

Vincent, S.R., and B.T. Hope (1990) Tyrosine hydroxylase containing neurons lacking aromatic amino acid decarboxylase in the hamster brain. J. Comp. Neurol. 295:290-298.

Vochteloo, J.D., and J.M. Koolhaas (1987) Medial amygdala lesions in male rats reduce aggressive behavior: Interference with experience. Physiol. Behav, 41:99-102

Warembourg, M., and P. Poulain (1991) Presence of estrogen receptor immunoreactivity in the oxytocin-containing magnocellular neurons projecting to the neurohypophysis in the guinea-pig. Neuroscience 40:41-53.

Whalen, R.E., and J.F. DeBold (1974) Comparative effectiveness of testoster one, androstenedione and dihydrotestosterone in maintaining mating behavior in the castrated male hamster. Endocrinology 95:1674-1679.

Wolf, M.E., M.J. Zigmond, and G. Kapatos (1989) Tyrosine hydroxylase content of residual striatal dopamine nerve terminals following 6 -hydroxydopamine administration: A flow cytometric study. J. Neurochem. 53:879-885

Wong, M., and R.L. Moss (1992) Modulation of single-unit activity in the rat medial amygdala by neurotransmitters, estrogen priming, and synaptic inputs from the hypothalamus and midbrain. Synapse 10:94-102.

Wood, R.I., and S.W. Newman (1993a) Mating activates androgen receptorcontaining neurons in the chemosensory pathways of the male Syrian hamster brain. Brain Res, in press.

Wood, R.I., and S.W. Newman (1993b) Intracellular partitioning of androgen receptor immunoreactivity in the brain of the male Syrian hamster: Effects of castration and steroid replacement. J. Neurobiol., in press.

Wood, R.I., R.K. Brabec, J.M. Swann, and S.W. Newman (1992) Androgen and estrogen receptor-containing neurons in chemosensory pathways of the male Syrian hamster brain. Brain Res. 596:89-98.

Zigmond, R.E. (1985) Biochemical consequences of synaptic stimulation The regulation of tyrosine hydroxylase activity by multiple transmitters. Trends Neurosci. 8:63-69.

Zolovick, A.J., D. Avrith, and J.E. Jalowiec (1980) Reversible colchicineinduced disruption of amygdaloid function in sodium appetite. Brain Res. Bull. 5:35-39. 